\title{
Portfolio investment as a factor for the development of the Russian economy as one of the BRIC countries
}

Magdalena Broszkiewicz*

\section{Introduction Portfolio investments - a theoretical framework}

The international investment position of countries takes into account their activity as an exporter and importer of capital in various forms. Due to the smaller size of flows in relation to direct investment and their more speculative character, as well as the possibility of the faster withdrawal of capital, portfolio investments in the world literature are rated as flows of minor importance for the development of the economies of the host countries. However, this is a significant simplification, omitting the impact of portfolio investments on the development of financial markets in the world, especially in countries of growing importance for the global economy. The issue of portfolio investments in the world economy is analyzed on the basis of data from the balance of payments of individual countries, and then aggregated by the International Monetary Fund and the World Bank.

The causes of international capital movements are sometimes identical to those that determine such flows within a given market (money supply and demand), and are also the sole cause for international movements. Due to the degree of political stability or the possibility of a higher return, some markets may seem more attractive than others. There are also speculative considerations, interest rate differences in money and capital markets, and an improvement in the structure of capital deposits (Bożyk et al. 2002, p. 115).A higher return on foreign assets may be justified by higher rates of growth in the countries where they originate. In addition, a low correlation between returns on assets is a significant reason for diversification, i.e., to properly compose portfolio components so that the investment

\footnotetext{
* Magdalena Broszkiewicz - PhD, Wroclaw University of Economics, Faculty of Economics, Department of Finance, magdalena.broszkiewicz@ue.wroc.pl.
} 
risk is minimal or profitable (according to the Markowitz theory) (Reilly, Brown 2011, p. 355). The World Bank's definition of a portfolio investment includes transactions of equity and debt securities through international financial markets. Equity net inflows are those, which include net inflows from equity securities other than those recorded as direct investment and including shares, stocks, depository receipts and direct purchases of shares in local stock markets by foreign investors (WB IDS). Bond securities in portfolio investment are issued with a fixed rate of interest for a period of more than one year. They include net flows through cross-border public and publicly guaranteed and private nonguaranteed bond issues (WB IDS). The most important feature of portfolio investment mentioned in the global literature is that in this case investors do not take active control over the institutions issuing securities, and are satisfied with the realization of profits. Profit is generated by the difference in exchange rates or fluctuations in interest rates, so investors often make their decisions on the basis of the ratings of the country.

Because of the trends of investment flows in the global economy, portfolio investments in developing countries have become more interesting in times of crisis. Russia is one of the countries which are mainly linked to the energy and raw materials sector, so at a time of fluctuations on those markets, its economy is less predictible for international investors. Russia is also an economy with large amounts of capital to invest, so its international investments, especially when it comes to portfolio investments, are worth studying.

This article is an attempt to analyze the flow of portfolio investments to and from the Russian Federation as one of the BRIC countries, in terms of geographi$\mathrm{cal}$ and historical conditions, taking into account the development of the domestic capital market. The analyses were carried out mainly on the basis of data published by the Bank of Russia. The foreign assets of the country include, among others, direct and portfolio investments invested abroad. Foreign liabilities include, among others, direct and portfolio investments made by foreign entities on the territory of the country.

\section{Conditions of the international investment position of Russia}

At the beginning of the twenty-first century, observations of the economies of developing countries aspiring to rapid promotion to the group of developed countries resulted in 4 countries being distinguished which had the greatest opportunities to enter the top tier of the world economy. In particular, the capital markets of Brazil, Russia, China and India developed very fast, which allowed investors from around the world to search for new places to invest capital in the form of portfolio investments. However, changes in global markets and the financial crises of the past 10 years have reduced the dynamics of the development of these 
states. Two interesting questions remain: what is the situation of the investment portfolio? And are the financial crises reflected in the direction of flow in the global economy?

Russia is a country belonging to the group of so-called BRIC countries (an acronym using the first letters of the names of the countries: Brazil, Russia, India, and China). Investing by using a portfolio strategy made up of stocks from these countries can be a safe solution because of the use of two types of diversity: sectoral and regional. These four countries are, in fact, culturally and geographically distant, but economically similar. They represent very different, lucrative sectors of the economy and are characterized by a multitude of advantages: economic growth, constantly increasing respect in the world economy, increased participation in the global markets, and developed BRIC companies.

The dynamics of their development was predicted to be higher than the growth rate of developed countries at the beginning of the $21^{\text {st }}$ century. Common feature of these four economies were: rapidly growing consumer demand and an increasinglly wealthy middle class. Until now, these countries have developed mainly due to foreign investments, linked to exports. At the moment, the main growth factor is domestic consumption.

Since the beginning of the $21^{\text {st }}$ century, analysts have predicted that a country included in the group of emerging markets in the near future will produce more world products (measured by purchasing power parity) than in developed economies. Before the financial crisis of 2008, it was predicted that in 2025 the BRIC countries alone would produce $40 \%$ of the world's GDP. This potential was represented by $85 \%$ of the world's population and covers about $40 \%$ of world trade. Reserves of foreign currencies of these countries were almost $70 \%$ of world reserves. However, the real growth opportunities can be seen in the capital markets as, to date, global stock market capitalization is only 10\% (Rosstat).

In addition, the rapidly expanding middle class (it is estimated that in the next 20 years their number will increase four-fold) and great dynamic of the growth of income per capita is a sign for investors to take into consideration portfolio investment in these countries.

The dynamic of growth of the BRIC economies can be seen by the composed index of the main stock companies on these four markets. Calculated by the US analytical institution Standard\& Poor's, the S\&P BRIC 40 is one of the stock indexes, weighted by capitalization, and without dividend protection (another one is, for example, the MSCI BRIC Index). It was launched on June 20, 2006 and is focused on the 40 companies which are the most important in Brazil, Russia, India and China. Companies from the index are traded on the stock exchanges in Sao Paulo, Moscow, Mumbai and Hong Kong. The market capitalization of companies in the index is $1,942.85$ billion USD for 2016 (S\&P a). The annual rate of return of the investment in companies from this index was $12.75 \%$ last year with a standard deviation (a measure of risk) of $19.62 \%$ in three years' time. 
After conducting a sectoral analysis, the dominating sector in the BRIC group is the financial sector and information technology companies. The energy sector, which dominated at the beginning of the $21^{\text {st }}$ century (over $40 \%$ in 2006), where oil and gas connected companies were the most important because of rising oil and gas prices, is now in third place, followed by the telecomunication sector (see Table 1). What is most important in the analyses of the index is that the sectoral breakdown is more differentiated. It creates an opportunity to build a portfolio investment avoiding too strong connections with one sector of the economy, especially with materials.

Table 1. Sector breakdown of S\&P BRIC 40 in 2006 and 2016 (in percent)

\begin{tabular}{|l|c|c|}
\cline { 2 - 3 } \multicolumn{1}{c|}{} & 2016 & 2006 \\
\hline Financials & 38.5 & 29.6 \\
\hline Information Technology & 31.3 & n.d. \\
\hline Energy & 12.6 & 41.4 \\
\hline Telecommunication Services & 5.9 & 13.1 \\
\hline Consumer Staples & 4.8 & n.d. \\
\hline Consumer Discretionary & 3.6 & n.d. \\
\hline Real Estate & 1.2 & n.d. \\
\hline Materials & 1.1 & 10.2 \\
\hline Industrials & 1.0 & n.d. \\
\hline Other & - & 5.7 \\
\hline
\end{tabular}

Source: own elaboration based on S\&P a.

The index can also be divided by the country of domicile of the companies. In 2016, most - 25 - were from China, 6 from Russia, 5 from Brazil, and 4 from India. The difference between that situation in 2008 is significant: China 17, Brasil 10, Russia 9, India 4. The biggest company from Russia which was involved in the index in 2008 was OAO Gazprom-Spon ADR REG S, which put it in second position of all companies in this index by index weight (S\&P b). In 2010, this company was in ninth position. The other companies involved historically in the index, listed on the Russian stock market are Sberbank, Rosneft, Lukoil, and Norilsk Nickel.

The BRIC economies were less exposed to shocks, which can be seen on more developed capital markets. There are, of course, moments in which stock markets of developing countries follow the declines in developed stock markets. In the short term, the investment risk is higher because of concerns about the impact of the situation across the ocean on the global market shares (the general 
situation on the financial markets is a significant risk), but in the long term, the growth potential of these economies, and thus the development prospects of companies in the BRIC countries, should be the maintained by the growth of share prices on these markets. A crisis in the US mortgages and banking sector, as one of the largest global financial markets, may cause repercussions in other countries. In the opinion of analysts, developing economies, including BRIC, are not greatly exposed to sudden changes in the situation in America and Western Europe. The only negative result could be a slowdown in growth.

The main trends of the behavior of investors on the capital markets of the world can be estimated by comparing charts presenting quotations of the S\&P BRIC 40 and the S\&P 500 (which groups the 500 largest companies in the world) indices in the period 2006-2016 (see Figure 1). The BRIC 40 index was launched in July 2006, and during the global financial crisis in 2008-2009 it recorded a growth well above the trading S\&P 500. In addition, during the crisis, the declines of the companies from the BRIC index were lower, suggesting a dynamic shift of capital from the markets of developed countries to the developing, in search of alternative investments. A similar situation was also observed during the recovery from the global financial crisis.

Figure 1. A comparison between S\&P BRIC 40 Index and S\&P 500 from 2006 to 2016 (2006=100)

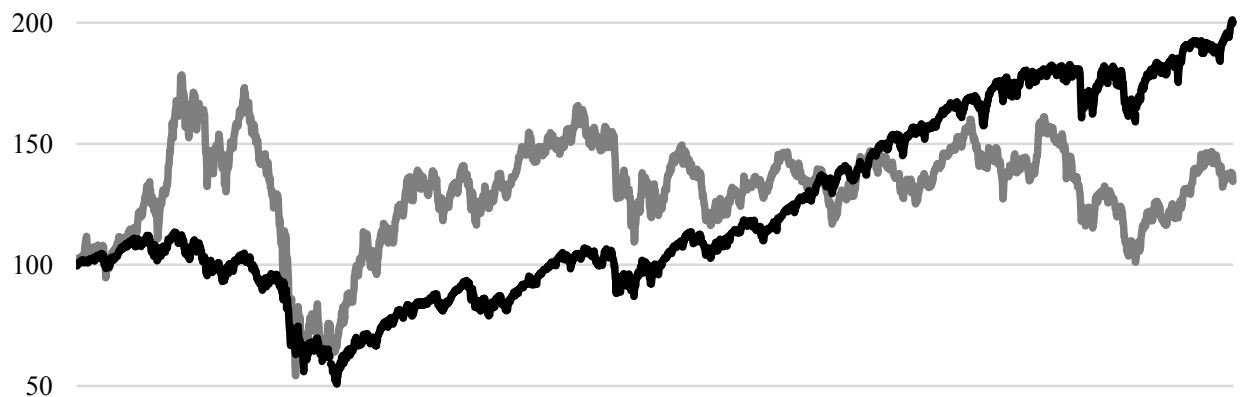

0

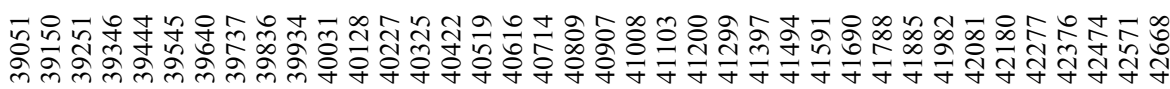

Source: own elaboration based on: S\&P c. 
In the period 2009-2013, companies from the BRIC countries were traded higher than companies in other regions of the world. The index at this time was mostly linked to companies from the energy and raw materials sectors. From 2013, the growing disproportion between global markets and the index of the BRIC countries was mainly due to declines in the prices of commodity companies and a stronger connection between the S\&P BRIC 40 with its financial and information technology sectors. Economic stagnation in developed countries, but also those aspiring to this name, contributed to the shift of capital in international markets in search of alternative, more profitable investments.

\section{The relationship with foreign investors}

Any assessment of the condition of the Russian economy is problematic - reserves of the central bank and the Stability Fund provide the development of macroeconomic stabilization, but they are insufficient in the case of declines in both oil prices and the ruble exchange rate. As a result, the decline in GDP in 2015 was as high as $3.7 \%$ (Rosstat).

As a result of changes in the structure of the economy, a new model of investments is necessary to improve the productivity and innovation of the Russian economy. Foreign investors also recognize that reforms in the field of anti-corruption and an increase in the transparency of Russian institutions are necessary (Żukowski 2009, p. 38).

Focusing the economy on the production of domestic technology also requires the participation of foreign capital and modern solutions. The liberalization of the economy and increasing the transparency of capital flows could increase the interest of foreign investors in the Russian market. At the same time, it is worth noting that the main Russian stock index - the MICEX - was in an upward trend in 2014 after earlier phases of volatility and stability (Trading Economics). A positive aspect of the Russian stock market's stabilization was achieved through the December 2011 merger of the Russian Trading System (RTS) and the Moscow Interbank Currency Exchange (MICEX). The process of integrating the largest stock exchanges was to allow for the faster privatization of state entities.

It should also be noted that portfolio investment in Russia revolves around the subjects with the largest capitalization on the Russian stock exchange. The 5 largest Russian companies - Gazprom, Sberbank, Rosneft, Lukoil, and Norilsk Nickel - make up approximately $50 \%$ of the total stock exchange capitalization. The 5 largest American companies in terms of capitalization on the stock exchange represent only $10 \%$ of the market capitalization (Thomson Reuters Datastream). This is a signal for foreign investors who want to invest their capital in Russia. As can be seen, companies indicated as entities with a majority state 
capital have strategic importance to the economy. Maintaining and subsidizing them by the state is also a kind of guarantee of return on investment for foreign capital. Basing their activities on raw materials gives the ability to make investments during periods of increases on the stock market, with adequate risk diversification.

The Russian government declared it was open to accepting foreign investment, and it encouraged residents to make investments in the country by establishing a number of regulations and limiting the outflow of capital from Russia, especially in the form of direct investment (USDS 2014, p. 3). But at the same time, the Russian government is blocking foreign direct investment in strategic sectors and holds majority stakes in companies whose value is approx. $50 \%$ of GDP. Russian law does not allow for the acquisition of controlling stakes in domestic companies by foreign investors.

Banks play the main role in the financial market of Russia, and the sector is dominated by state property. This fact influenced the quick exit of finance flows from the Russian market during the financial crisis of 2008, because they were supported by the decisions of the state. But this is not a situation conducive to the development of competition or raising the level of financial services in Russia. The interest of foreign investors in the Russian stock market is, therefore, due to the possibility of making short-term investments, and not long-term capital investment in Russia.

Since 2013, the Central Bank of Russia has been the main regulator of the financial markets in the country, including the capital markets. Its main task is to conduct the consolidation of the banking sector needed in the economy, but also to reduce the gray market outflows of capital from Russia to tax havens and to observe the process of money laundering. In the share of portfolio investments flowing to Russia, we can see that the role of investing capital in debt is growing, even though it is still lower than equity-related investments (see Figure 2).

The increasing interest of foreign investors in Russian debt securities is caused by the opinion that it is a safe alternative to developed financial markets, where the crisis has caused large fluctuations. The domestic market of debt securities is also subject to pressure from the financial authorities of the country (reducing the value of the ruble) in order to encourage foreign investors to invest in them. Russian government securities (OFZ) from 2012 can also be traded outside the country of the issuer. In February 2013, Euroclear and Clearstream, two international securities depositories, began listing Russian debt, making an effort to list commercial and municipal assets. These actions facilitate transactions in Russia's securities market without involving middlemen-residents. 
Figure 2. A comparison of Russian portfolio investments (net) with portfolio equity net inflows and portfolio investment in bonds from 2007 to 2015 (in bln current USD)
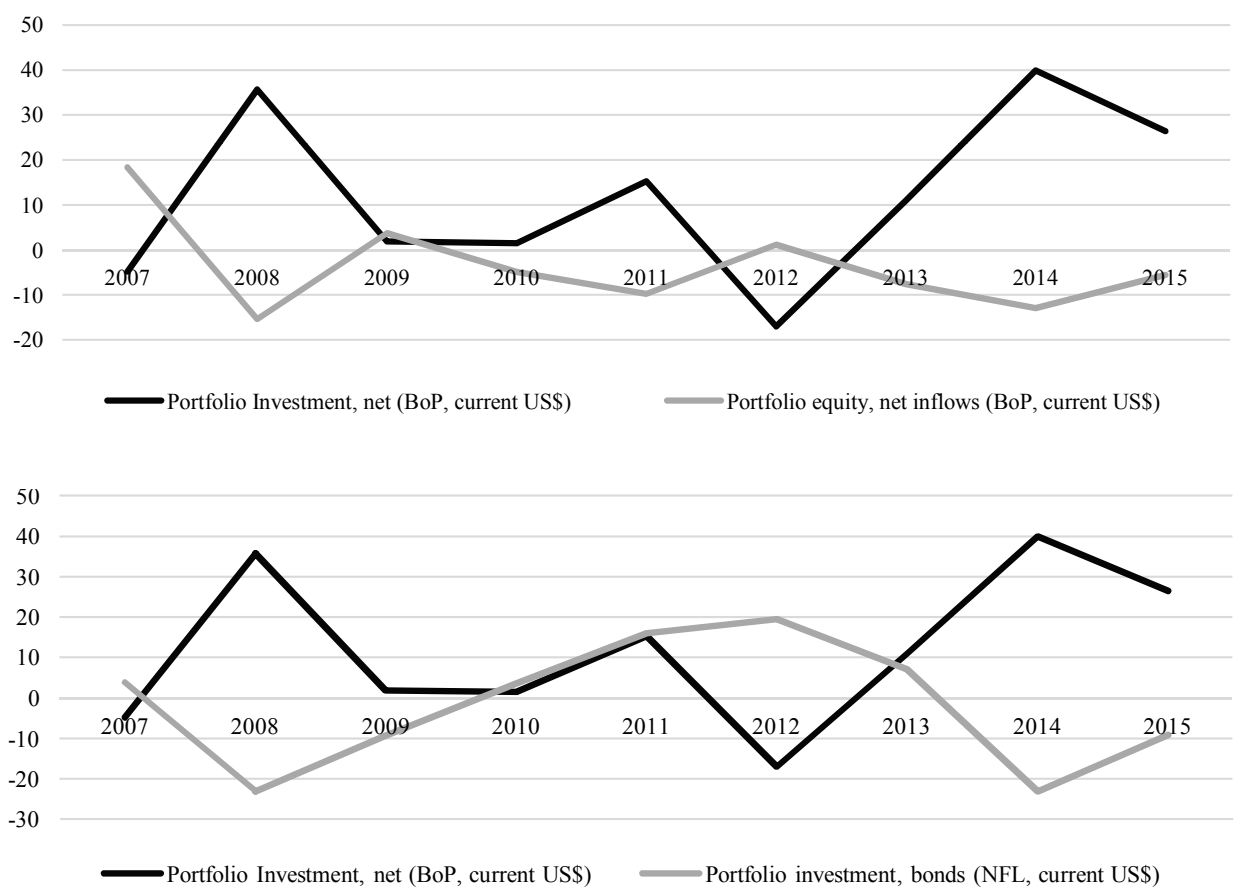

Source: WB WDI.

Government regulations and good practice on stock exchanges in the field of making investments for residents and non-residents constitute the basis for powerful business capital. To allow such a flow, it is necessary to create a friendly environment for investors and guarantee respect for the fundamental rights of investors. Russia still needs many reforms in this field to be able to attract capital, both short- and long-term.

Table 2. The protection of investors in Russia in comparison with developed and developing economies

\begin{tabular}{|l|c|c|c|c|}
\cline { 2 - 5 } \multicolumn{1}{c|}{} & Russia & $\begin{array}{r}\text { Eastern Europe } \\
\text { \& Central Asia }\end{array}$ & United States & Germany \\
\hline $\begin{array}{l}\text { Index of Transaction } \\
\text { Transparency }\end{array}$ & 6.0 & 7.0 & 7.0 & 5.0 \\
\hline $\begin{array}{l}\text { Index of Manager's } \\
\text { Responsibility }\end{array}$ & 2.0 & 5.0 & 9.0 & 5.0 \\
\hline $\begin{array}{l}\text { Index of Shareholders' } \\
\text { Power }\end{array}$ & 6.0 & 6.0 & 9.0 & 5.0 \\
\hline $\begin{array}{l}\text { Index of Investor } \\
\text { Protection }\end{array}$ & 4.7 & 5.9 & 8.3 & 5.0 \\
\hline
\end{tabular}

Source: own elaboration based on Doing Business (2016). 
The indicators contained in Table 2 which show the protection of interests of investors indicate the shortcomings of the Russian market in terms of these regulations. The transparency of transactions does not differ significantly from the global average, nor does the possibility of investor action in terms of managing the company. But in the area of managers' responsibility for the decisions of the companies, new regulations are required to increase their scope. Similarly, in the protection of the interests of shareholders, it is necessary to undertake reforms and to increase the safety of investors for their attraction to the Russian market.

\section{Portfolio investment inflows to Russia}

The inflow of portfolio investments to BRIC countries over the last 15 years was very diverse and resulted both from the investment position of each of the countries in this group, as well as the fluctuations in global financial markets. On the chart below (see Figure 3), we can see a stronger inflow of portfolio investments to China in 2006, but the presence in the global markets of the Russian market as an alternative to investment in the crisis was also noted in 2008. Russia is practically the only country in the BRIC group which in this period was mostly a net importer of capital in the form of portfolio investments. In particular, China and Brazil became net exporters of capital in the form of portfolio investments in the period after the financial crisis in 2008.

Figure 3. The history of portfolio investment in BRIC countries 2001-2015, net (in bln current USD)

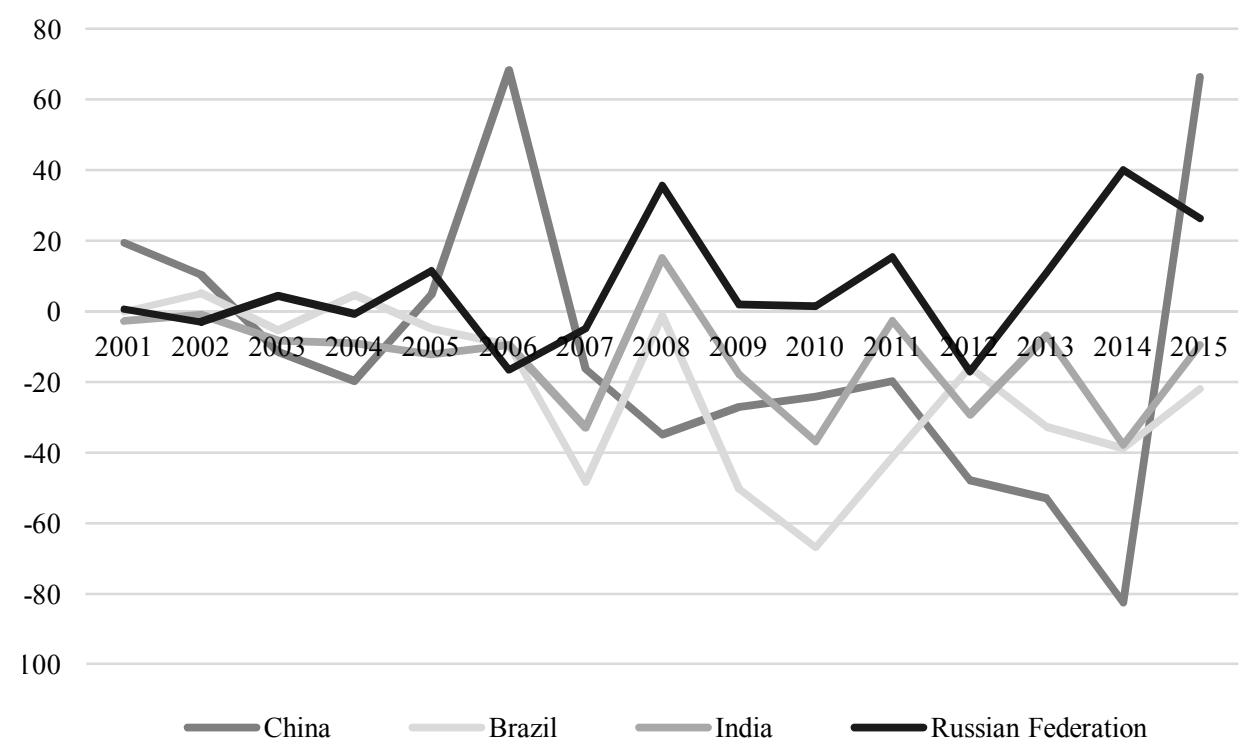

Source: own elaboration based on WB IDS. 
The history of portfiolio investment in Russia has changed dramatically since 1997. No data are available from before 1994 for the International Monetary Fund (Tikhomirov 2000, p. 43). Starting from 1995, a clear upward trend in capital inflows to Russia can be observed. It continued until 1997, which was a record in the category of the inflow of foreign investments to Russia $-\$ 4.8$ billion. Russia acquired many foreign investors and reached $14^{\text {th }}$ place among the largest world importers of FDI. Interest in portfolio investments also increased, in particular in state securities, which resulted in short-term profits amounting to several tens of percent. However, the financial crisis in 1998shookinvestors' trust in the Russian market (see Figure 4).Overall, however, it is noted that in comparison with direct investment, portfolio investment played only a minor role in the development of the Russian economy after the collapse of the Soviet Union (Kłosiński, Wancio 2011, p. 132).

The return of strong interest from foreign investors in the Russian economy, in the form of direct and portfolio investments, started in 2000 and lasted until 2006 , when a temporary fall in net portfolio investment inflows can be observed. In 2007, a significant increase in the investment portfolio on the liabilities side of the balance of payments can be observed (see Table 4), the majority of which flowed into the equity and investment fund shares. 2007 was a record year in terms of the inflow of foreign investments to Russia - compared to the previous year, the increase more than doubled. According to Rosstat, the volume of portfolio investments for 2007 amounted to 366,660 million USD, 38.1\% more than their value in 2006 .

Figure 4. History of portfolio investment in Russia, net (in bln current USD)

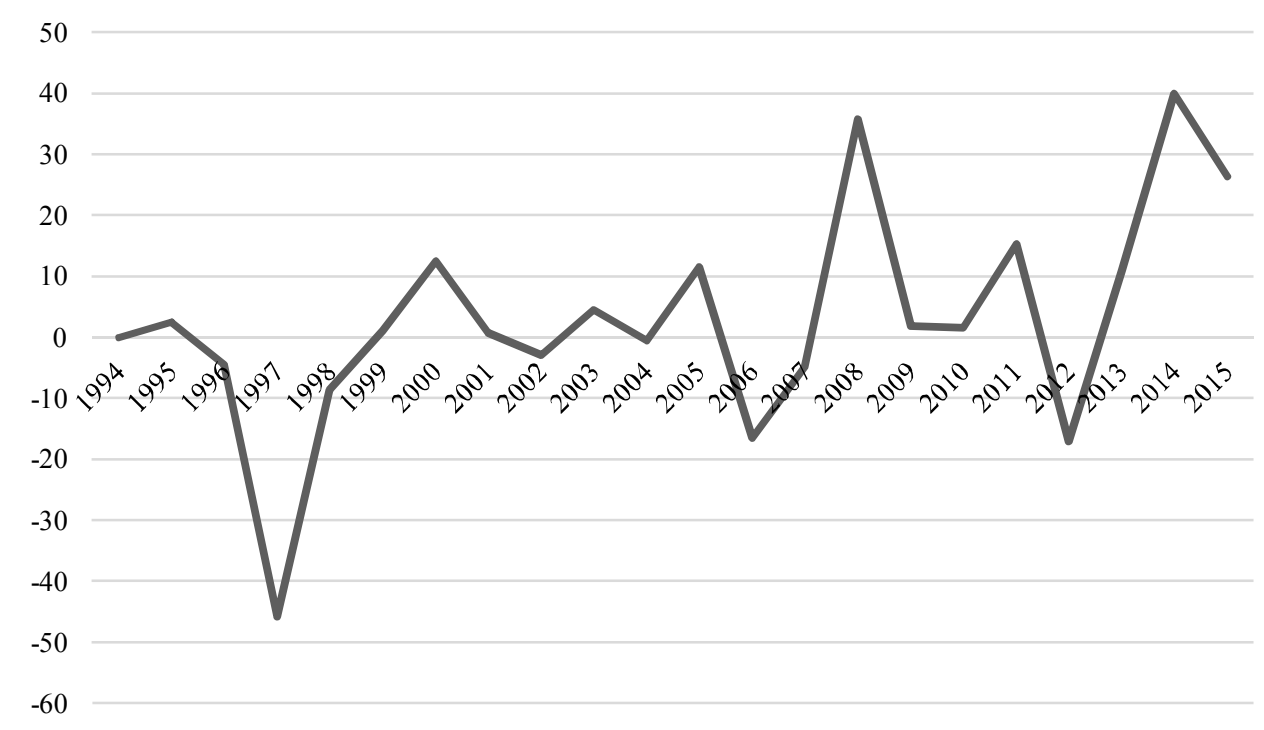

Source: own elaboration based on WB IDS. 


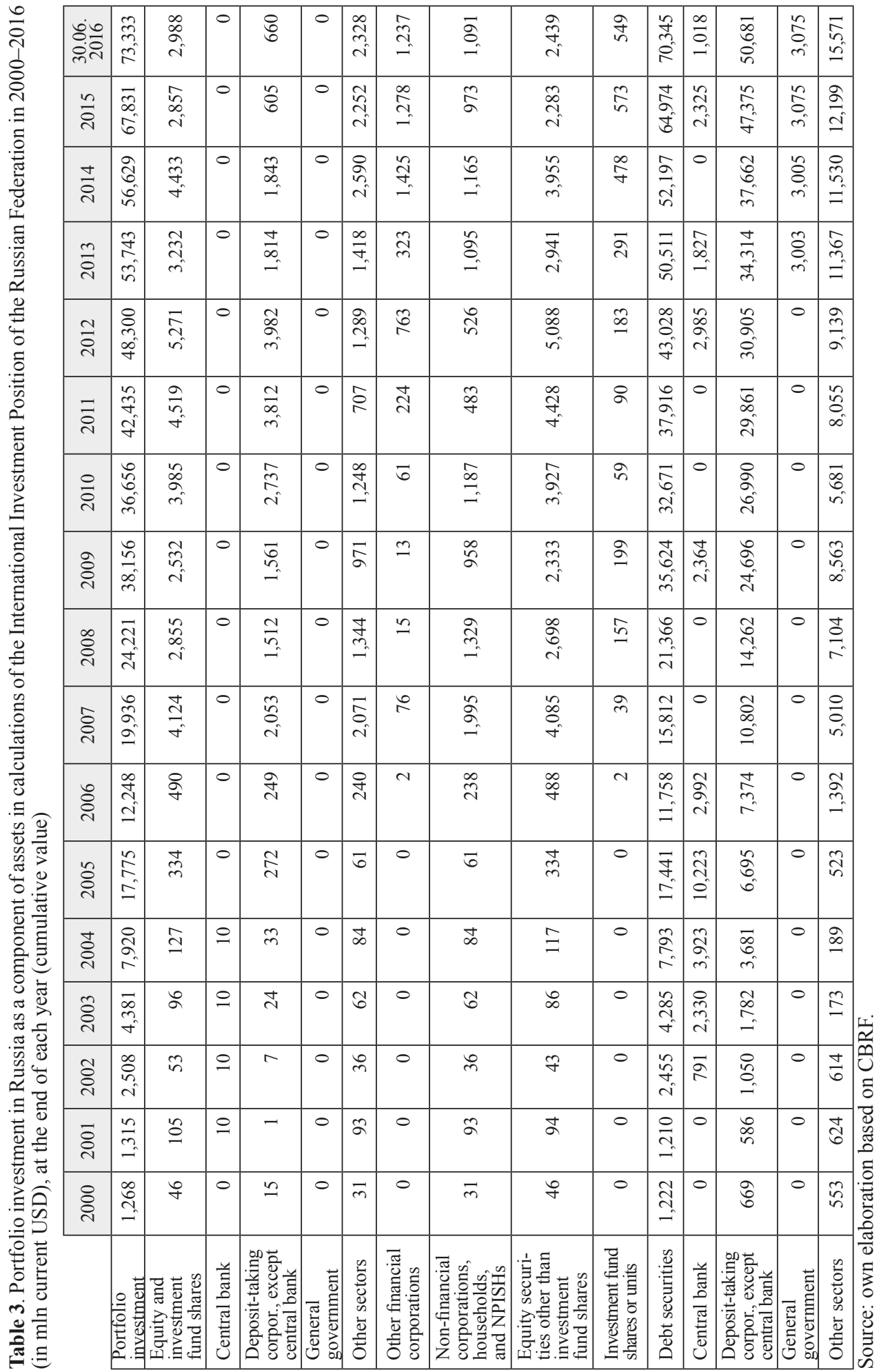




\begin{tabular}{|c|c|c|c|c|c|c|c|c|c|c|c|c|c|c|}
\hline & 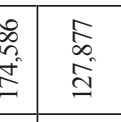 & \begin{tabular}{|l|}
0 \\
\end{tabular} & \multicolumn{2}{|c|}{ 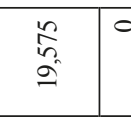 } & 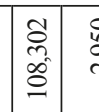 & \multicolumn{2}{|c|}{ 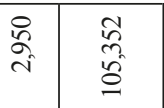 } & 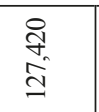 & \multicolumn{2}{|c|}{ 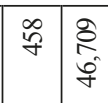 } & & $\begin{array}{ll}8 \\
3 \\
0 \\
0\end{array}$ & \\
\hline 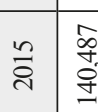 & 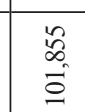 & 0 & 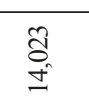 & & 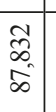 & 䍘 & 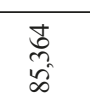 & 鈢 & 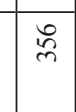 & 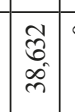 & & $\bar{\pi}$ & 兽: & \\
\hline 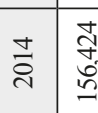 & $\stackrel{8}{E}$ & 0 & 尌 & & 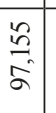 & 8 & 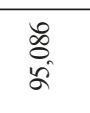 & 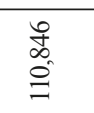 & $\mathscr{ஜ}$ & 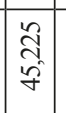 & & $\frac{a}{6}$ & 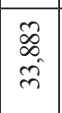 & \\
\hline 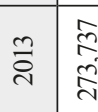 & $\begin{array}{l}\text { to } \\
\text { o. } \\
\underline{g}\end{array}$ & & $\begin{array}{l}\text { 兽 } \\
\text { d. }\end{array}$ & & $\begin{array}{l}0 \\
0 \\
0 \\
0 \\
0 \\
0\end{array}$ & $\bar{\gamma}$ & 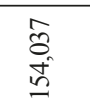 & $\begin{array}{l}\text { 案 } \\
\text { d }\end{array}$ & 㤐 & 管 & o & त्रे & 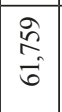 & \\
\hline ग) & 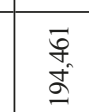 & 0 & 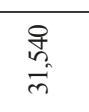 & & 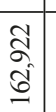 & 8 & $\begin{array}{l}\tilde{n} \\
\vdots \\
\vdots \\
\underline{2}\end{array}$ & $\frac{8}{2}$ & & 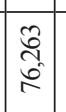 & c & $\frac{8}{\alpha}$ & & 8 \\
\hline 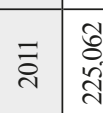 & 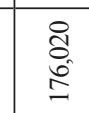 & 0 & $\begin{array}{l}\overrightarrow{\mathrm{D}} \\
\mathrm{i} \\
\mathrm{i}\end{array}$ & 0 & 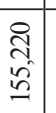 & $\frac{5}{\infty}$ & $\begin{array}{l}8 \\
8 \\
\pm\end{array}$ & 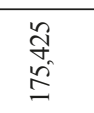 & & 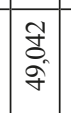 & & 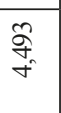 & & \begin{tabular}{|l|}
$\tilde{y}$ \\
$\tilde{z}$
\end{tabular} \\
\hline 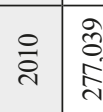 & 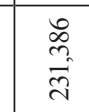 & 10 & 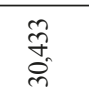 & 0 & $\begin{array}{c}0 \\
\vdots \\
\vdots \\
\vdots \\
\vdots\end{array}$ & $\stackrel{8}{=}$ & $\begin{array}{l}\text { 美 } \\
\text { 总 }\end{array}$ & 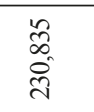 & 呙 & 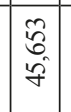 & & $\overline{\text { z্ }}$ & 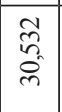 & 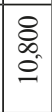 \\
\hline ذ্ণ & 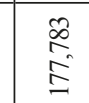 & 10 & \begin{tabular}{l}
0 \\
\multirow{2}{*}{} \\
d
\end{tabular} & 0 & 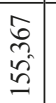 & $\frac{0}{2}$ & 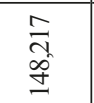 & 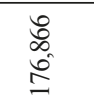 & $\bar{\sigma}$ & 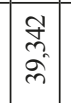 & & $\stackrel{\circ}{\stackrel{\circ}{f}}$ & 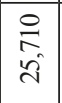 & $\frac{15}{10}$ \\
\hline 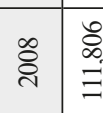 & $\begin{array}{l}\substack{\infty \\
\infty \\
\infty \\
\infty} \\
\infty\end{array}$ & 0 & $\underset{\infty}{0}$ & 0 & 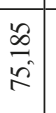 & 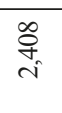 & 吾 & $\begin{array}{l}\vec{b} \\
\dot{\infty}\end{array}$ & œ & 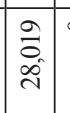 & & त్ర్ర & \begin{tabular}{|l|}
$\underline{n}$ \\
$\underline{0}$ \\
\end{tabular} & \\
\hline \begin{tabular}{c|c}
$\delta$ \\
:
\end{tabular} & $\begin{array}{l}\text { 总 } \\
\text { of } \\
\text { of }\end{array}$ & 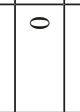 & 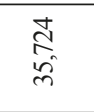 & 0 & 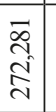 & 它 & $\begin{array}{l}\sqrt{2} \\
\vdots \\
\vdots \\
d\end{array}$ & $\begin{array}{l}8 \\
8 \\
0\end{array}$ & ธू' & 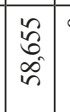 & & $\frac{\sigma}{6}$ & 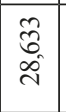 & \\
\hline 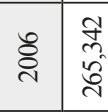 & $\begin{array}{l}\text { 喿 } \\
\text { 客 }\end{array}$ & 10 & 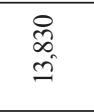 & 0 & 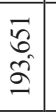 & $\frac{\sqrt{2}}{\sqrt[5]{2}}$ & $\frac{\sigma}{\partial}$ & $\begin{array}{l}3 \\
\vdots \\
\vdots \\
0\end{array}$ & $\bar{\infty}$ & \begin{tabular}{|c|}
$\vec{s}$ \\
$\dot{i}$ \\
$i n$
\end{tabular} & & $\overline{m_{2}}$ & 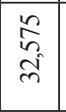 & 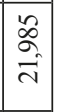 \\
\hline 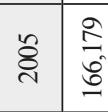 & $\begin{array}{l}\stackrel{5}{0} \\
\stackrel{\Phi^{\circ}}{=}\end{array}$ & 0 & 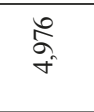 & 0 & 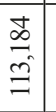 & 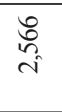 & 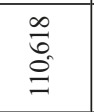 & $\begin{array}{l}\stackrel{\circ}{0} \\
\stackrel{0}{\leftrightarrows} \\
=\end{array}$ & \pm & 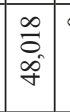 & & 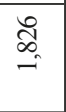 & 呄 & 5 \\
\hline 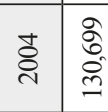 & 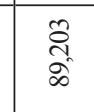 & 0 & I & 0 & 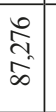 & 足 & $\begin{array}{l}8 \\
8 \\
0 \\
0\end{array}$ & $\frac{\infty}{\infty}$ & 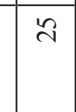 & 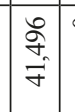 & & $\underset{\sim}{a}$ & 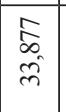 & \\
\hline 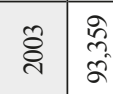 & $\begin{array}{l}\text { s. } \\
\text { on } \\
i n\end{array}$ & o & $\stackrel{\infty}{=}$ & & 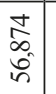 & 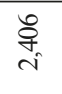 & 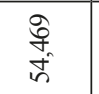 & : & 0 & 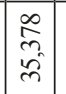 & & $\mathcal{I}$ & 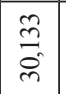 & 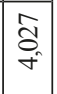 \\
\hline 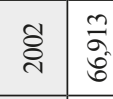 & d & 10 & $\widetilde{\tilde{b}}$ & 0 & $\begin{array}{ll}8 \\
m \\
m \\
m\end{array}$ & 多 & id & $\begin{array}{l}0 \\
0 \\
0 \\
m\end{array}$ & & \begin{tabular}{|l|}
$\vec{n}$ \\
$\vec{m}$ \\
\end{tabular} & & : & 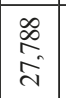 & \\
\hline 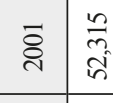 & 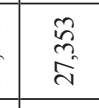 & 0 & & 0 & 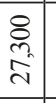 & + & 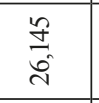 & 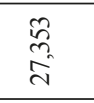 & $\circ$ & 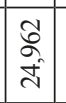 & & $\stackrel{3}{\rightarrow}$ & 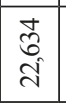 & \\
\hline 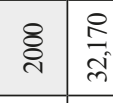 & $\stackrel{g}{\Rightarrow}$ & & $\approx$ & & $\overline{8}$ & 棌 & $\begin{array}{l}\stackrel{8}{8} \\
\stackrel{8}{0} \\
\end{array}$ & $\stackrel{g}{=}$ & 0 & \begin{tabular}{|l|}
$\vec{b}$ \\
$\vec{a}$ \\
\end{tabular} & ల్ల & 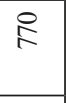 & \begin{tabular}{|l|}
$\infty$ \\
6 \\
0 \\
9
\end{tabular} & \\
\hline & & & & & & & & & & & & & & \\
\hline
\end{tabular}


In 2008, an increase in the inflow of portfolio investments on a net basis can be observed on year to year calculations. This is caused by the methodology of calculating changes due to credit and debit entries, which are recorded on a net basis separately for financial assets and liabilities. Financial account balances are calculated as the change in assets minus the change in liabilities; signs are reversed from previous editions (WB IDS). However, the analysis of the balance of payments data (Tables 3 and 4) shows integrating Russia with the global market reduced the proportion of capital flows and investor activity, both on the assets and liabilities.

The capital invested in the form of portfolio investments is fragile and often short-term, and it is most vulnerable to periods of recession, causing rapid changes in the flow of this kind of capital. These relationships can be clearly observed in 2008 in Russia. While in the first half of the year declines were relatively slow, from September 2008 their magnitude grew, depicting a drop in foreign investors' interest in the Russian securities market. This translated into a decline on the Russian stock market - the RTS Index declined over the year by $73 \%$, reaching the level of a decade previously. The declines affected all sectors of the economy (Moscow Exchange - History). The major exporters of capital to Russia in the discussed period were Cyprus, the United Kingdom, the Netherlands, Germany, Luxembourg, France and the United States.

After 2008, portfolio investment liabilities again grew. In 2009 and 2010, the level was close to pre-crisis values. Similar values remained in 2012-2013 after a slight decline recorded in 2011, probably due to fluctuations on the world markets. However, in 2014, portfolio investment recorded a decrease in Russia. This can be explained by the geopolitical situation and the lack of confidence in the stability of the Russian economy. The major exporters of capital to Russia in 2014 (data without distinction on the type of investment) were Cyprus, the Netherlands, the Bahamas, Bermuda, Germany, and Switzerland (Rosstat).

As we can see in Tables 3 and 4, there is a large surplus of capital inflows in portfolio investments over their outflow from Russia (the excess of liabilities over assets of the balance of payments in the investment portfolio). It may also be noted that the inflow of portfolio investments is directed primarily to equity securities other than investment fund shares (mainly in non-financial corporations, households and NPISHs - non-profit institutions serving households). The remaining inflows are concentrated in the area of investment fund shares or units. Since 2001, capital invested in debt securities other than in share units has had a smaller share in the inflow of portfolio investments in Russia. However, we can observe dynamic growth in both types of inflows (in equity and debt securities) during the period, interrupted only in 2008 because of the crisis in the financial markets. Since 2009, the inflow of portfolio investment into Russia remains significant.

Analyzing the assets of Russian portfolio investments, it is necessary to emphasize the importance of political decisions: forced to take long-term investments in the domestic economy, Russian capital in the form of portfolio investment is 
focused on achieving quick profits abroad - not on creating significant purchases of foreign securities. In fact, the majority of Russian foreign investment is short-term and speculative. Most Russian capital goes to places seen as tax havens (see Table 5). Comparing the amount of capital exported to these countries from Russia to the value of local Russian direct investment shows clearly that money will flow only through these countries, not stay in them. The presence of tax havens, such as Cyprus and the British Virgin Islands, in Russia's top 10 investment locations, demonstrates the attractiveness of both confidentiality in investments abroad and a low tax burden for invested capital (CEIC).

Table 5. Portfolio investment assets, top 10 destinations from Russia (total portfolio investment by year, in mln current USD)

\begin{tabular}{|c|c|c|c|c|c|c|c|c|}
\hline & 2008 & Value & 2009 & Value & 2010 & Value & 2011 & Value \\
\hline 1 & Luxembourg & 5,666 & Luxembourg & 10,454 & Luxembourg & 8,827 & Luxembourg & 11,534 \\
\hline 2 & Ireland & 5,024 & Ireland & 9,139 & Ireland & 6,554 & Ireland & 9,356 \\
\hline 3 & United States & 2,673 & United States & 4,160 & UK & 4,673 & Cyprus & 5,236 \\
\hline 4 & Netherlands & 2,483 & Netherlands & 3,433 & Cyprus & 4,633 & UK & 4,748 \\
\hline 5 & Virgin Islands & 1,889 & Cyprus & 2,840 & Netherlands & 3,938 & Netherlands & 4,142 \\
\hline 6 & Cyprus & 1,877 & Virgin Islands & 2,061 & United States & 1,954 & Jersey & 1,704 \\
\hline 7 & UK & 1,318 & $\begin{array}{l}\text { International } \\
\text { Organizations }\end{array}$ & 1,552 & $\begin{array}{l}\text { International } \\
\text { Organizations }\end{array}$ & 1,315 & United States & 1,681 \\
\hline 8 & Germany & 889 & UK & 1,499 & Australia & 1,034 & $\begin{array}{l}\text { International } \\
\text { Organizations }\end{array}$ & 1,215 \\
\hline 9 & Australia & 780 & Germany & 976 & Germany & 867 & Canada & 947 \\
\hline \multirow[t]{2}{*}{10} & $\begin{array}{l}\text { International } \\
\text { Organizations }\end{array}$ & 505 & Australia & 617 & Jersey & 818 & Virgin Islands & 662 \\
\hline & 2012 & Value & 2013 & Value & 2014 & Value & 2015 & Value \\
\hline 1 & Ireland & 11,070 & Luxembourg & 15,469 & Luxembourg & 16,664 & Luxembourg & 24,612 \\
\hline 2 & Luxembourg & 11,000 & Ireland & 15,041 & Ireland & 15,328 & Ireland & 19,379 \\
\hline 3 & UK & 6,379 & Netherlands & 3,967 & Cyprus & 5,679 & Netherlands & 4,420 \\
\hline 4 & Netherlands & 4,186 & Ukraine & 3,059 & Netherlands & 4,652 & United States & 3,514 \\
\hline 5 & Cyprus & 2,735 & Cyprus & 2,917 & UK & 3,118 & Cyprus & 2,468 \\
\hline 6 & $\begin{array}{l}\text { International } \\
\text { Organizations }\end{array}$ & 2,346 & $\begin{array}{l}\text { International } \\
\text { Organizations }\end{array}$ & 1,496 & Ukraine & 3,005 & Jersey & 920 \\
\hline 7 & Germany & 2,145 & Jersey & 847 & Jersey & 1,972 & Switzerland & 260 \\
\hline 8 & United States & 2,079 & United States & 707 & United States & 1,972 & Virgin Islands & 154 \\
\hline 9 & Jersey & 1,480 & Germany & 541 & $\begin{array}{l}\text { International } \\
\text { Organizations }\end{array}$ & 604 & Turkey & 90 \\
\hline 10 & France & 1,329 & Canada & 537 & Canada & 317 & Bermuda & 83 \\
\hline
\end{tabular}

Source: own elaboration based on CPIS (2016). 
The data above shows that Russian investors are looking for places to invest capital in order to achieve short-term gains and tax benefits. Portfolio investment flowing from Russia is speculative capital, easy to move in terms of any change in the conditions of the functioning of global financial markets. It is, therefore, capital which may contribute to the increasing instability of financial markets in the host countries.

\section{Conclusions}

Interconnected international financial markets affect the transmission of both positive and negative signals for making an investment. This applies to both developed and developing economies, including BRIC countries. The fluctuations seen in the portfolio of Russian portfolio investments in the $21^{\text {st }}$ century are due both to world trends and to the country's political and economic relations.

The Russian economy, since the beginning of the twenty-first century, has experienced a significant influx of foreign capital, including in the form of portfolio investment. However, in comparison with the possibilities of the development of the economic potential of Russia it is still a small amount. Domestic investments are still considered to be the most important in the process of creating economic growth and development in a country. However, increasing the interest of foreign investors in Russia and the power of capital can contribute to independence from external factors, especially energy exports associated with the global conjuncture of prices for these goods.

Closing certain sectors (considered strategic) on foreign capital may contribute to the inhibition of their investment and thus the development of the economy. Due to the high dependence of the Russian economy on raw materials, it remains a high-risk market for foreign capital, including in the form of portfolio investments.

\section{Bibliography}

Bożyk P., Misala J., Puławski M. (2002), Międzynarodowe stosunki ekonomiczne, PWE, Warsaw.

CBRF, External Sector Statistics, The Central Bank of the Russian Federation, http://www.cbr.ru/eng/statistics/?Prtid=svs (accessed: 20 December, 2016).

CEIC, Foreign Investment Outflow from Russia Headed to Europe, https://www. ceicdata.com/en/blog/foreign-investment-outflow-russia-headed-europe (accessed: 15 December, 2016).

CPIS (2016), Coordinated Portfolio Investment Survey, International Monetary Fund, http://data.imf.org/?sk=B981B4E3-4E58-467E-9B90-9DE0C3367 363\&sId=1481577785817 (accessed: 12 December, 2016). 
Doing Business (2016), World Bank, http://data.worldbank.org/data-catalog/doing-business-database (accessed: 15 January, 2017).

Kłosiński K., Wancio A. (2011), Inwestycje zagraniczne w Rosji, Roczniki Ekonomii i Zarządzania, Vol. 3, No. 39.

Moscow Exchange - History, https://moex.com/en/Report/2013/history.html (accessed: 16 January, 2017).

Reilly F. K., Brown K. C. (2011), Investment analysis and portfolio management, Cengage Learning, Boston.

Rosstat, Russian Federation Federal State Statistic Service, http://www.gks.ru/wps/ wcm/connect/rosstat_main/rosstat/en/figures/domestic/ (accessed: 15 December, 2017).

S\&P a, Ratings Direct, http://us.spindices.com/indices/equity/sp-bric-40-index (accessed: 15 December, 2017).

S\&P b, S\&P BRIC 40, http://www.fondsprofessionell.de/upload/attach/221920. pdf (accessed: 15 December, 2017).

S\&P c, S\&P Dow Jones Indices, http://www.spindices.com/ (accessed: 16 January, 2017).

Thomson Reuters Datastream, http://financial.thomsonreuters.com/en/products/ tools-applications/trading-investment-tools/datastream-macroeconomicanalysis.html (accessed: 21 December, 2017).

Tikhomirov V. (2000), The Political Economy of Post-Soviet Russia, Palgrave Macmillan UK.

Trading Economics, Rosja - Indeks Giełdowy, http://pl.tradingeconomics.com/ russia/stock-market (accessed: 21 December, 2017).

USDS (2014), U.S. Department of State: 2014 Investment Climate Statement, https://www.state.gov/documents/organization/228199.pdf (accessed: 21 December, 2016).

WB IDS, International Debt Statistics, World Bank, http://data.worldbank.org/ indicator/BX.PEF.TOTL.CD.WD?end=2015\&start $=1960 \&$ view $=$ chart\&ye ar=2015 (accessed: 21 December, 2017).

WB WDI, World Development Indicators, World Bank, http://databank.worldbank.org/data/reports.aspx? source $=2 \&$ series $=$ BN.KLT.PTXL.CD\&country (accessed: 17 December, 2017).

Żukowski M. (2009), Finding the path out of crisis, [in:] Kwaśnik Z., Żukow W., Aktualne wyzwania ekonomii, Radomska Szkoła Wyższa, Radom.

\section{Summary}

Portfolio investments have an impact on the development of financial markets around the world, especially in countries of growing importance for the global economy. Russia is one of the countries which are mainly linked to the energy and 
raw materials sector, so at a time of fluctuations on those markets, its economy is less predictible for international investors.

The regulations for investors in this country (also non-residents) need to be improved to overcome the negative effects of world financial crisises and to rebuild financial markets. Russia is also an economy with large amounts of capital to invest, so it is interesting to observe its financial flows to other countries in the situation when existing regulations are stopping capital for domestic investment.

The following article analyzes the flows of portfolio investment in Russia in the twenty-first century based on balance of payments data in conjunction with changes in the geopolitical situation and the investment attractiveness of the country.

Capital invested in the form of portfolio investments is fragile and often short-term, and it is most vulnerable to periods of recession, causing rapid changes in the flow of this kind of capital. These relationships can be clearly observed in Russia. The strong interest of foreign investors in the Russian economy, in the form of direct and portfolio investments, started in 2000 and lasted until 2006. In the first half of 2008, decreases were slow compared to the record high of the previous year, but from September they accelerated to such an extent that by the end of the year they had reached almost $100 \%$, depicting a sharp decline of foreign investors' interest in the Russian securities market. This translated into a decline on the Russian stock market. The Russian economy since the beginning of the twenty-first century has experienced a significant influx of foreign capital, including in the form of portfolio investment. However, in comparison with the possibilities of the development of the economic potential of Russia, it is still a small amount.

Keywords: portfolio investment, Russia, international financial flows

\section{Streszczenie}

\section{Inwestycje portfelowe - czynnik rozwoju gospodarki rosyjskiej jako jednego z krajów BRIC}

Inwestycje portfelowe mają niewątpliwy wpływ na rozwój światowych rynków finansowych, szczególnie w przypadku krajów o rosnącym znaczeniu dla światowej gospodarki. Rosja jest jednym z krajów, których gospodarka jest bardzo silnie związana z wydobywaniem surowców naturalnych oraz ze źródłami energii nieodnawialnej, w związku z czym w okresie wahań na rynkach tych dóbr cała gospodarka staje się mniej przewidywalna dla inwestorów.

Regulacje rynku finansowego Rosji dla inwestorów krajowych i zagranicznych powinny zostać przeformułowane w taki sposób, aby redukować efekty negatywnych zdarzeń na międzynarodowych rynkach finansowych i odbudować rynek wewnętrzny. Rosja posiada znaczące rezerwy kapitału, które można przeznaczyć na inwestycje, więc interesującą kwestią pozostaje kierunek przepływu 
inwestycji portfelowych z Rosji do innych krajów w czasie, kiedy rodzimy rynek nie stwarza zachęt do inwestycji na rynku finansowym.

W zaprezentowanym artykule zawarto rozważania na wskazane tematy, wykorzystując bilans płatniczy Rosji i informacje o inwestycjach portfelowych w ujęciu napływu kapitału na ten rynek i jego odpływu wraz z analizą atrakcyjności inwestycyjnej tego kraju.

Inwestycje portfelowe uważane za mniej znaczące dla gospodarki kraju przyjmującego i często krótkoterminowe są najbardziej podatne na okresy recesji, które powodują gwałtowne zmiany w przepływie tego rodzaju kapitału. Zjawisko to można wyraźnie zaobserwować w gospodarce Rosji. Silne zainteresowanie zagranicznych inwestorów gospodarką rosyjską w formie inwestycji bezpośrednich i portfelowych rozpoczęło się w $2000 \mathrm{r}$. i trwało do $2006 \mathrm{r}$. W związku z trendami światowymi i kryzysem gospodarczym w pierwszej połowie 2008 r. na rynku kapitałowym w Rosji odnotowano znaczne spadki (w porównaniu z rokiem poprzednim wyniosły prawie $100 \%$, co wskazuje na spadek zainteresowania inwestorów zagranicznych rosyjskim rynkiem papierów wartościowych). Rosyjska gospodarka od początku XXI wieku doświadczyła znacznego napływu kapitału zagranicznego, w tym $\mathrm{w}$ formie inwestycji portfelowych. Jednak w porównaniu z możliwościami rozwoju potencjału gospodarczego Rosji jest to nadal niewielka liczba.

Słowa kluczowe: inwestycje portfelowe, Rosja, międzynarodowe przepływy finansowe

JEL: F21, G15 